Jap. J. Limnol. 45, 1, 38-43, 1984.

\title{
Partitioning of Heavy Metals into Mineral and Organic Fractions in Sediments from a Reservoir
}

\author{
Masahiro SAKATA
}

\begin{abstract}
A sediment core was collected from S Reservoir, which is located in the western part of Okayama Prefecture. The vertical distribution of heavy metals ( $\mathrm{Fe}, \mathrm{Mn}, \mathrm{Zn}, \mathrm{Ni}, \mathrm{Cu}$ and $\mathrm{Cd}$ ) and fine particles $(<37 \mu \mathrm{m})$ was measured. The heavy metal contents of the sediment core are relatively high in small grain layers. Partitioning of heavy metals into $\mathrm{NH}_{2} \mathrm{OH} \cdot \mathrm{HCl}$ soluble, $\mathrm{H}_{2} \mathrm{O}_{2}$ soluble and $\mathrm{HF}$ soluble fractions has been determined with a selective chemical leaching technique on the sediment samples. The greatest parts of $\mathrm{Mn}$ and $\mathrm{Cd}$ are contained in the $\mathrm{NH}_{2} \mathrm{OH} \cdot \mathrm{HCl}$ soluble fraction (mostly iron and manganese oxide and hydroxide coatings on silicate minerals), whereas more than $50 \%$ of $\mathrm{Fe}, \mathrm{Zn}$, $\mathrm{Ni}$ and $\mathrm{Cu}$ is present in the $\mathrm{HF}$ soluble fraction (silicate lattice). The variations of heavy metal contents in the sediment core are chiefly due to those in $\mathrm{NH}_{2} \mathrm{OH} \cdot \mathrm{HCl}$ soluble and $\mathrm{HF}$ soluble fractions. Only manganese is significantly enriched in the $\mathrm{NH}_{2} \mathrm{OH} \cdot \mathrm{HCl}$ soluble fraction of the settling material collected by the sediment trap near the bottom, probably due to the release of manganese from bottom sediment into overlying water. Manganese oxide and hydroxide reprecipitated under oxic conditions of the bottom water after the release might have been effectively collected by the sediment trap.
\end{abstract}

\section{Introduction}

Thousands of reservoirs have been constructed in Japan for energy use, flood control and water supply. Recently, more attention has been paid to the environmental quality of reservoirs, as in natural lakes. Reservoirs are often very different from natural lakes especially in their hydrologies, which significantly affect the sedimentation and water quality of reservoirs (WRIGHT, 1967; WUNDERLICH, 1971; Soltero et al., 1975; Bertine and Walawender, 1978; Martine and Arneson, 1978; CARMACK et al., 1979; GLOSS et al., 1980).

In order to obtain base-line data for the sedimentation of heavy metals in reservoirs or freshwater ponds, partitioning of heavy metals ( $\mathrm{Fe}, \mathrm{Mn}, \mathrm{Zn}, \mathrm{Ni}, \mathrm{Cu}$ and $\mathrm{Cd}$ ) into $\mathrm{NH}_{2} \mathrm{OH} \cdot \mathrm{HCl}$ soluble, $\mathrm{H}_{2} \mathrm{O}_{2}$ soluble and $\mathrm{HF}$ soluble fractions has been determined with a selective chemical leaching technique on core and settling material samples collected from S Reservoir, Japan. A selective chemical leaching technique might be effective in determining geochemical behavior of heavy metals.

\section{Study Area}

S Reservoir, one of the largest reservoirs in Japan, is located in the western part of Okayama Prefecture. It was built in 1968 mainly to provide hydroelectric power and industrial water. Morphometric data for the reservoir at maximum capacity (surface elevation $237 \mathrm{~m}$ ) are given below: max. depth, $100 \mathrm{~m}$; mean depth, $35 \mathrm{~m}$; area, $3.6 \times 10^{6} \mathrm{~m}^{2}$; volume, $128 \times 10^{6} \mathrm{~m}^{3}$. The direct supply of heavy metals due to human activities is minimal in this reservoir. The investigation of water quality of S Reservoir was reported by AkI et al. (1982).

\section{Experimental}

\section{3-1. Sampling}

A sediment core was taken near the dam of S Reservoir in May, 1979 (surface elevation $233 \mathrm{~m}$ ) by gravity corer. The water depth of the sampling station was $82 \mathrm{~m}$. Immediately after collection, the sediment core was cut into $3 \mathrm{~cm}$ horizontal slices for chemical analyses. These samples were then sealed in a plastic container and stored at about $4^{\circ} \mathrm{C}$ until analysis. 
Settling materials were collected by sediment trap at about $20 \mathrm{~m}$ and $70 \mathrm{~m}$ (5-15 $\mathrm{m}$ above the bottom) water depths of the same station as sediment core over the time period of a year (May 21, 1979 to May 15, 1980). The sediment trap consists of 8 polyethylene bottles with diameter of $4.5 \mathrm{~cm}$ and height of $1.8 \mathrm{~cm}$. After collection, the samples were sealed in a plastic container and stored at about $4^{\circ} \mathrm{C}$ until analysis.

Core and settling material samples were dried at $110^{\circ} \mathrm{C}$, and chemical analyses were carried out on the powdered samples.

\section{3-2. Determination of Partitioning}

The partitioning of six heavy metals ( $\mathrm{Fe}, \mathrm{Mn}, \mathrm{Zn}, \mathrm{Ni}, \mathrm{Cu}$ and $\mathrm{Cd}$ ) into $\mathrm{NH}_{2}-$ $\mathrm{OH} \cdot \mathrm{HCl}$ soluble, $\mathrm{H}_{2} \mathrm{O}_{2}$ soluble and $\mathrm{HF}$ soluble fractions of the sediment samples was determined by the selective chemical leaching technique (Presley et al., 1972; Kitano et al., 1981). Fe, Mn, Zn, Ni and $\mathrm{Cu}$ were determined by air-acetylene flame atomic absorption spectrometry, whereas $\mathrm{Cd}$ was determined by graphite furnace atomic absorption spectrometry after the addition of $0.5 \% \quad\left(\mathrm{NH}_{4}\right)_{2} \mathrm{SO}_{4}$ solution as the matrix modifier to the sample solution (SAKATA and Shimoda, 1982).

1) $\mathrm{NH}_{2} \mathrm{OH} \cdot \mathrm{HCl}$ soluble fraction: One $\mathrm{g}$ of a dry sample was treated with $25 \mathrm{ml}$ of $1 \mathrm{M} \mathrm{NH} \mathrm{NH}_{2} \mathrm{OH} \cdot \mathrm{HCl}$ solution in $0.1 \mathrm{~N} \mathrm{HCl}$ for 12 hours at room temperature. This treatment was intended to leach heavy metals in ferro-manganese oxides, carbonates and acid soluble sulfides (FeS), and in ion-exchangeable forms in clay minerals without leaching of heavy metals in organic and silicate lattice fractions. However, heavy metals other than copper in organic fraction may be partially leached with this treatment (KITANo and SaKata, 1978).

2) $\mathrm{H}_{2} \mathrm{O}_{2}$ soluble fraction: The residue remaining after the $\mathrm{NH}_{2} \mathrm{OH} \cdot \mathrm{HCl}$ treatment is then digested with $25 \mathrm{ml}$ of $30 \% \mathrm{H}_{2} \mathrm{O}_{2}$ in $0.01 \mathrm{~N} \mathrm{HCl}$ while heating. This treatment leaches heavy metals associated with organic material and pyrite $\left(\mathrm{FeS}_{2}\right)$ which remain after the preceding $\mathrm{NH}_{2} \mathrm{OH} \cdot \mathrm{HCl}$ treatment.

3) $\mathrm{HF}$ soluble fraction: The residue, after $\mathrm{NH}_{2} \mathrm{OH} \cdot \mathrm{HCl}$ treatment and then $\mathrm{H}_{2} \mathrm{O}_{2}$ treatment, consists almost entirely of detrital silicate minerals. The residue is dissolved by $\mathrm{HF}(10 \mathrm{~m} l)-\mathrm{HNO}_{3}(10 \mathrm{~m} l)$ $\mathrm{HClO}_{4}(5 \mathrm{ml})$ digestion. Heavy metals in this solution are regarded as those from the silicate fraction excluding those from exchangeable sites.

$3-3$. Determination of fine particle $(<37 \mu \mathrm{m})$ The grain-size separation was achieved by sieving a well-mixed sediment. The fraction that passed through a sieve of 400 mesh (JIS, $37 \mu \mathrm{m}$ ) was defined as fine particle of sediment, and expressed in weight percentage for the dry sediment.

\section{3-4. Determination of total carbon and sulfur}

Total carbon in the sediment was determined with a CHN analyzer (Yanagimoto Model MT-2).

Total sulfur in the sediment was determined by infrared absorption photometry through the combustion of the sample in a high-frequency induction furnace (TERASHIMA, 1978).

\section{Results and Discussion}

Figure 1 shows the vertical distribution of six heavy metals ( $\mathrm{Fe}, \mathrm{Mn}, \mathrm{Zn}, \mathrm{Ni}, \mathrm{Cu}$ and $\mathrm{Cd})$, fine particle $(<37 \mu \mathrm{m})$ and total carbon and sulfur in the sediment core. The heavy metal contents of the core are relatively high in small grain layers. The variations of fine particle $(<37 \mu \mathrm{m})$ percentage and also heavy metal contents in the sediment core may be attributed to the occurrence of storms with heavy rainfall which carries larger sizes of sediments.

The results of a selective chemical leaching for the sediment core and the settling material collected near the bottom are shown in Fig. 2.

1) Heavy metals in $\mathrm{NH}_{2} \mathrm{OH} \cdot \mathrm{HCl}$ soluble fraction: The percentages of heavy metal contents are 23 to $28 \%$ for Fe, 69 to $81 \%$ for $\mathrm{Mn}, 20$ to $38 \%$ for $\mathrm{Zn}, 27$ to $39 \%$ for $\mathrm{Ni}, 20$ to $24 \%$ for $\mathrm{Cu}$ and 76 to $85 \%$ for 


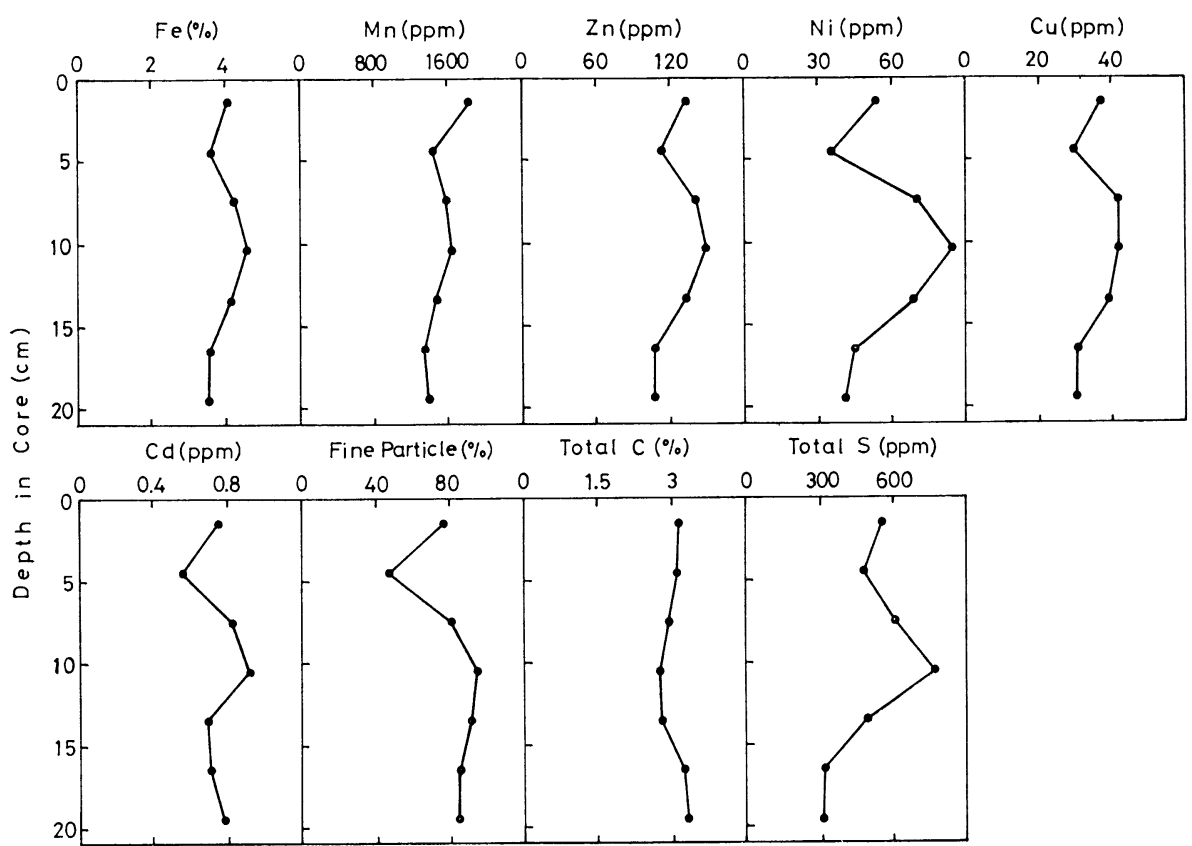

Fig. 1. Vertical distribution of six heavy metals (Fe, $\mathrm{Mn}, \mathrm{Zn}, \mathrm{Ni}, \mathrm{Cu}$ and $\mathrm{Cd}$ ), fine particle $(<37 \mu \mathrm{m})$ and total carbon and sulfur in the sediment core.

Cd. The greatest parts of manganese and cadmium are contained in this fraction. There is a significant correlation between iron content in the $\mathrm{NH}_{2} \mathrm{OH} \cdot \mathrm{HCl}$ soluble fraction and manganese, zinc, nickel, copper and cadmium contents in the fraction (correlation coefficients: Mn 0.66, Zn 0.88, Ni 0.94, Cu 0.98, Cd 0.73). Heavy metals leached from the sediments with the $\mathrm{NH}_{2} \mathrm{OH} \cdot \mathrm{HCl}$ treatment are therefore regarded chiefly to be associated with iron and manganese oxides (and hydroxides). The heavy metal contents of sulfide, carbonate and ion-exchangeable fractions are very small relative to that of the oxide fraction. This may be supported by the fact that iron monosulfide $(\mathrm{FeS})$, carbonate and clay are almost absent in the sediments. The vertical profiles of heavy metals in the $\mathrm{NH}_{2} \mathrm{OH} \cdot \mathrm{HCl}$ soluble fraction are similar to those in the entire sediment (Figs. 1 and 2). The heavy metal contents of the $\mathrm{NH}_{2} \mathrm{OH} \cdot \mathrm{HCl}$ soluble fraction are relatively high in small grain layers. Most parts of iron and manganese oxides (and hydroxides) in the sediments are present as coatings on the particles of silicate minerals (JENnE, 1968; SuAREZ and LANGMUIR, 1976). The smaller particle of sediment contains the larger amount of iron and manganese oxide coatings and also trace metals associated with those coatings.

Only manganese is significantly enriched in the $\mathrm{NH}_{2} \mathrm{OH} \cdot \mathrm{HCl}$ soluble fraction of settling material, as seen from Fig. 2. It is known that in $\mathrm{S}$ Reservoir manganese is released from bottom sediment into overlying water during summer and autumn, as a result of the dissolution of manganese oxide and hydroxide under anoxic conditions within the sediments (AKI et al., 1982). The estimated average flux of manganese from bottom sediment is about $10 \mu \mathrm{g} \cdot \mathrm{cm}^{-2} \cdot \mathrm{day}^{-1}$ (AKI et al., 1982), which is very important as compared with the average sedimentation rate of manganese oxide of $21 \mu \mathrm{g} \cdot \mathrm{cm}^{-2} \cdot \mathrm{day}^{-1}$. The average sedimentation rate of manganese oxide was obtained from the 

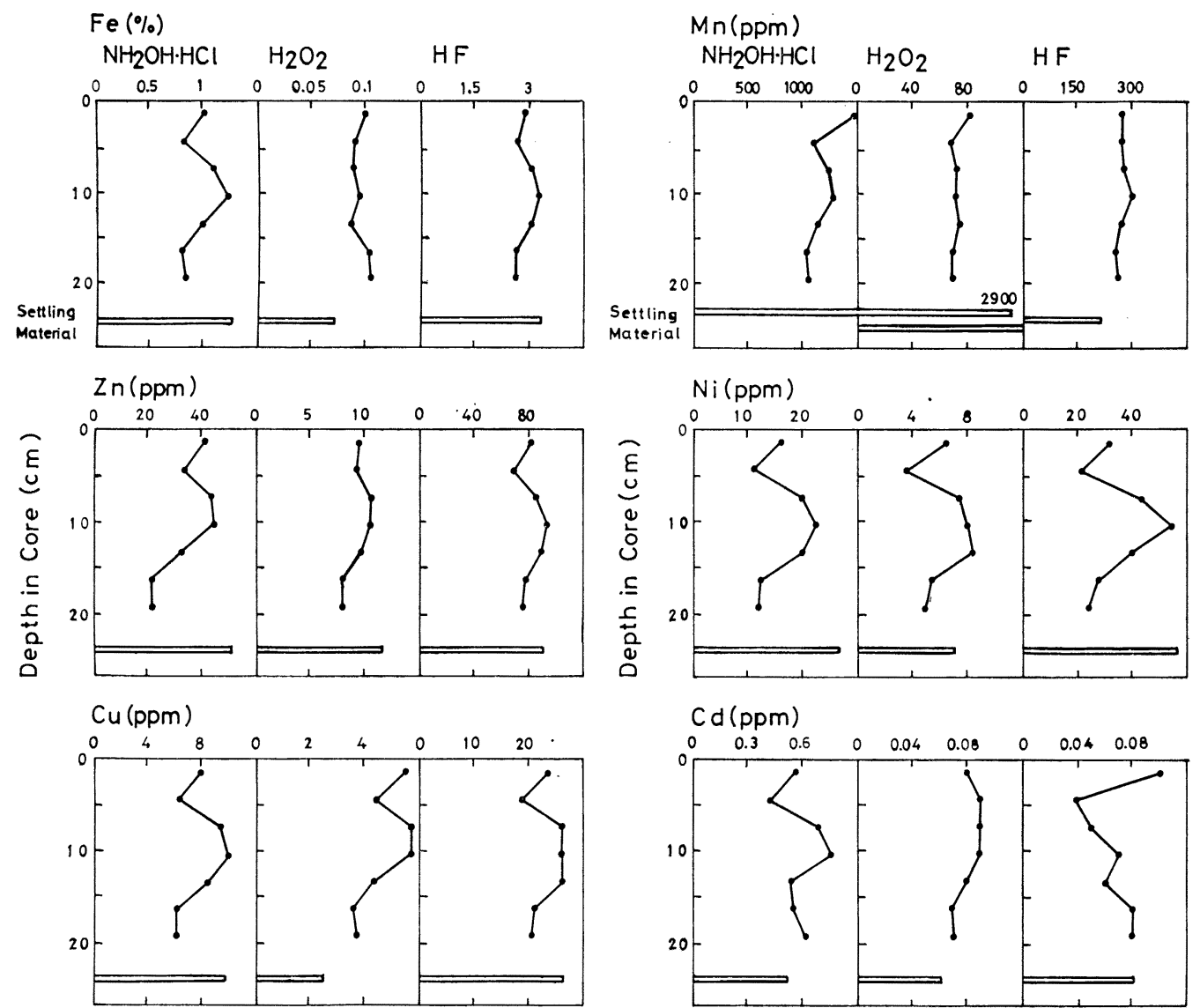

Fig. 2. Results of a selective chemical leaching for the sediment core and the settling material collected near the bottom.

sediment trap collection: average sediment flux $\times$ manganese content of the $\mathrm{NH}_{2} \mathrm{OH}$. $\mathrm{HCl}$ soluble fraction $7.1 \mathrm{mg} \cdot \mathrm{cm}^{-2} \cdot \mathrm{day}^{-1} \times$ $2900 \mu \mathrm{g} \cdot \mathrm{g}^{-1}$. The enrichment of manganese in the $\mathrm{NH}_{2} \mathrm{OH} \cdot \mathrm{HCl}$ soluble fraction of the settling material is probably attributed to the release of manganese from bottom sediment into overlying water. Manganese oxide and hydroxide reprecipitated under oxic conditions of the bottom water after the release might have been effectively collected by the sediment trap, because the manganese content $(1530 \mathrm{ppm})$ in the $\mathrm{NH}_{2} \mathrm{OH} \cdot \mathrm{HCl}$ soluble fraction of the settling material collected at about $20 \mathrm{~m}$ water depth is not significantly higher than that of the sediment core (1040-1480 ppm). Except for manganese content, the heavy metal contents in the settling materials collected at about $20 \mathrm{~m}$ water depth and near the bottom are nearly equal to those in the sediment core. Most heavy metals except for manganese transported to the bottom are considered to be incorporated into the bottom sediment.

2) Heavy metals in $\mathrm{H}_{2} \mathrm{O}_{2}$ soluble fraction: The percentages of heavy metal contents in the $\mathrm{H}_{2} \mathrm{O}_{2}$ soluble fraction for their total contents are 2 to $3 \%$ for $\mathrm{Fe}, 4$ to $5 \%$ for $\mathrm{Mn}, 6$ to $8 \%$ for $\mathrm{Zn}, 9$ to $14 \%$ for $\mathrm{Ni}, 11$ to $17 \%$ for $\mathrm{Cu}$ and 8 to $16 \%$ for $\mathrm{Cd}$. The proportions of heavy metals in this fraction are relatively small. The $\mathrm{H}_{2} \mathrm{O}_{2}$ treatment leaches heavy metals associated with organic material and pyrite $\left(\mathrm{FeS}_{2}\right)$ which remain after the preceding 
$\mathrm{NH}_{2} \mathrm{OH} \cdot \mathrm{HCl}$ treatment. However, heavy metals leached with the $\mathrm{H}_{2} \mathrm{O}_{2}$ treatment are regarded as chiefly from the organic fraction, due to the following. The average molar ratio of total sulfur content to iron content in the $\mathrm{H}_{2} \mathrm{O}_{2}$ soluble fraction is 0.91 , which is fairly smaller than the value of pure pyrite $\left(\mathrm{Fe}_{2} \mathrm{~S}\right)$. There is no distinct correlation between total sulfur content and iron content in the $\mathrm{H}_{2} \mathrm{O}_{2}$ soluble fraction. According to the data of BoweN (1979), the average weight ratios of carbon to sulfur in seed plants, algae and plankton, which are principal sources of organic materials in the sediments, are 103, 29 and 38 , respectively. The average weight ratio of total carbon to total sulfur in the sediments from S Reservoir is 60, which is higher than in organic materials. These results suggest that the pyrite content of the sediments from S Reservoir is significantly small. Thus, heavy metals leached with the $\mathrm{H}_{2} \mathrm{O}_{2}$ treatment are regarded as chiefly from the organic fraction.

3) Heavy metals in HF soluble fraction: Heavy metals in the HF soluble fraction are regarded as those from silicate fraction excluding those from exchangeable sites. The percentages of heavy metal contents in the HF soluble fraction for their total contents are 69 to $74 \%$ for Fe, 15 to $26 \%$ for $\mathrm{Mn}, 55$ to $72 \%$ for $\mathrm{Zn}, 47$ to $65 \%$ for $\mathrm{Ni}, 60$ to $68 \%$ for $\mathrm{Cu}$ and 5 to $13 \%$ for $\mathrm{Cd}$. More than $50 \%$ of $\mathrm{Fe}, \mathrm{Zn}, \mathrm{Ni}$ and $\mathrm{Cu}$ in the sediments are contained in this fraction, and the vertical profiles of those heavy metals in the HF soluble fraction are similar to those in the entire sediment (Figs. 1 and 2). This result is probably related to the variation in the silicate mineral composition of the sediments.

In summary, the results of a selective chemical leaching of the core sediment samples show that the greatest parts of $\mathrm{Mn}$ and $\mathrm{Cd}$ are contained in the $\mathrm{NH}_{2} \mathrm{OH}$. $\mathrm{HCl}$ soluble fraction (mostly iron and manganese oxide and hydroxide coatings on silicate minerals), whereas more than $50 \%$ of $\mathrm{Fe}, \mathrm{Zn}, \mathrm{Ni}$ and $\mathrm{Cu}$ is present in the $\mathrm{HF}$ soluble fraction (silicate lattice).
The variations of heavy metal contents in the sediment core occur chiefly due to those in $\mathrm{NH}_{2} \mathrm{OH} \cdot \mathrm{HCl}$ soluble and $\mathrm{HF}$ soluble fractions. Only manganese is significantly enriched in the $\mathrm{NH}_{2} \mathrm{OH} \cdot \mathrm{HCl}$ soluble fraction of the settling material collected by the sediment trap near the bottom, probably due to the release of manganese from bottom sediment into overlying water. Manganese oxide and hydroxide reprecipitated under oxic conditions of the bottom water after the release might have been effectively collected by the sediment trap.

\section{Acknowledgements}

We thank Professor Y. Kitano (Nagoya University) and Messrs. O. Shimoda and M. Koizumi (Central Research Institute of Electric Power Industry) for their critical reviewing of the manuscript, and Dr. E. Matsumoto (Geological Survey of Japan) for his help in the determination of sulfur in the sediment.

\section{摘要}

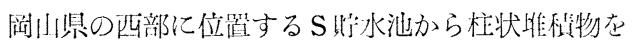
採取し, 堆碽物中の重金属元䇣 $(\mathrm{Fe}, \mathrm{Mn}, \mathrm{Zn}, \mathrm{Ni}$, $\mathrm{Cu}$ および $\mathrm{Cd})$ と微細粓子 $(<37 \mu \mathrm{m})$ の鉛直分布

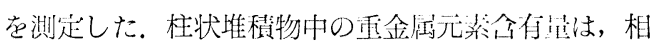
対的に粒径の小さい屏において高い颉们を小した。 分 別溶解法を用いて, 准桯物中け $\mathrm{NH}_{2} \mathrm{OH} \cdot \mathrm{HCl}, \mathrm{H}_{2} \mathrm{O}_{2}$ および HF 可浴性: fraction への重金属元采の分配 を測定した。准梖物中の Mn と Cd の大部分は,

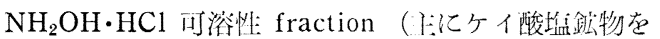
被覆した鉄とマンガンの酸化物や水和陖化物相）中に

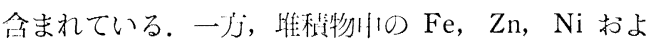
$ひ ゙ C u の 50 \%$ 以上は, HF 叮深性: fraction (イオン

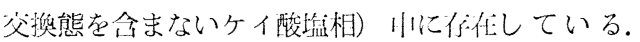

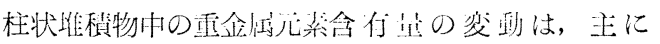
$\mathrm{NH}_{2} \mathrm{OH} \cdot \mathrm{HCl}$ および $\mathrm{HF}$ i丁溛性: fraction 川O含有

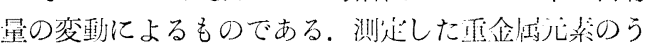
ち Mnだけは, sediment trapにより湖底近くで捕 集された沈降粒子小门 $\mathrm{NH}_{2} \mathrm{OH} \cdot \mathrm{HCl}$ 㞴溶性: fraction

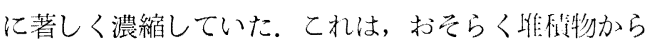

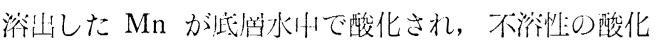
物や水和酸化物となったものが, sediment trap に より捕集されたためである.

\section{References}

Aki, S., O. Shimoda, T. Shirasuna, T. AkaSaki, Y. Miyanaga and M. Sakata (1982): Reservoir water quality-investigation and 
analysis (in Japanese). CRIEPI Rep. No. 302, Central Research Institute of Electric Power Industry (Japan).

Bertine, K. K. and S. J. Walawender (1978): Chronological strategies and metal Huxes in semi-arid lake sediments. Geochim. Cosmochim. Acta, 42: 1559-1571.

Bowen, H. J.M. (1979) Environmental Chemistry of the Elements. Academic Press, London.

Carmack, E.C., C. B. Gray, C.H. Pharo and R. J. Daley (1979) : Importance of lake-river interaction on seasonal patterns in the general circulation of Kamloops Lake, British Columbia. Limnol. Oceanogr., 24: 634-644.

Gloss, S. P., L. M. Mayer and D. E. Kidd (1980) : Advection control of nutrient dynamics in the epilimnion of a larger reservoir. Limnol. Oceanogr., 25: 219-228.

Jenne, E. A. (1968) : Controls on Mn, Fe, Co, $\mathrm{Ni}, \mathrm{Cu}$ and $\mathrm{Zn}$ concentration in soils and water: the significant role of hydrous $\mathrm{Mn}$ and Fe oxides, p. 337-387. In: R. A. BAKer (ed.), Trace Inorganics in Water, Adv. Chem. Ser. No. 73, American Chemical Society.

Kitano, Y. and M. Sakata (1978) : Behavior of heavy metals in river input to the ocean system. p.66-76. In: Proceedings of the Colloquium on Aquatic Environment in Pacific Region, SCOPE: Acad. Sinica, Taipei.

Kitano, Y., M. Sakata and E. Matsumoto (1981) : Partitioning of heavy metals into mineral and organic fractions in a sediment core sample from Osaka Bay. J. Oceanogr. Soc. Japan, 37: p59-266.

Martine, D. B. and R. D. Arneson (1978): Comparative limnology of a deep-discharge reservoir and a surface discharge lake on the Madison River, Montana. Freshwater Biol., 8: $33-42$.
Presley, B. J., Y. Kolodny, A. Nissenbaum and I. R. Kaplan (1972) : Early diagenesis in a reducing fjord, Saanich Inlet, British Columbia-II. Trace element distribution in interstitial water and sediment. Geochim. Cosmochim. Acta, 36: 1073-1090.

SaKata, M. and O. Shimoda (1982): A simple and rapid method for the determination of lead and cadmium in sediment by graphite furnace atomic absorption spectrometry. Water Res., 16: 231-235.

Soltero, R.A., A.F. Gasperino and W.G. Graham (1975): Chemical and physical characteristics of a eutrophic reservoir and its tributaries; Long Lake, Washington-2. Water Resour. Res., 9: 1059-1064.

Suarez, D. L. and D. Langmuir (1976) : Heavy metal relationships in a Pennsylvania soil. Geochim. Cosmochim. Acta, 40: 589-598.

Terashima, S. (1978): The rapid determination of total carbon and sulfur in geological materials by combustion and infrared absorption photometry. Anal. Chim. Acta, 101: 25-31.

Wright, J.C. (1967) : Effects of impoundments on productivity, water chemistry, and heat budgets of rivers, p. 188-199. In: Reservoir Fisheries Resources, Symp. Am. Fish. Soc. Spec. Publ.

Wunderlich, W. O. (1971): The dynamics of density stratified reservoirs, p. 219-231. In: G.E. Hall (ed.), Reservoir Fisheries and Limnology, Am. Fish. Soc. Spec. Publ. 8.

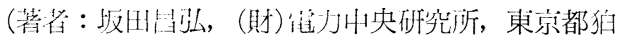
江术岩局北 2-11-1； Masahiro Sakata, Central Research Institute of Electric Power Industry, 2-11-1, Iwato Kita, Komae-shi, Tokyo 201)

Accetped: 8 August 1983 